ISSN : 2356-4164

\title{
HERMENEUTIKA SEBAGAI METODE PENEMUAN HUKUM YANG PROGRESIF
}

\author{
Andika Wahyudi Gani \\ STIEM Bongaya Makassar \\ Email: ganiandika@gmail.com
}

\begin{abstract}
ABSTRAK
Kehidupan manusia begitu luas aspeknya sehingga tidak bisa seluruh kehidupan manusia didefinisikan dalam suatu aturan perundang-undangan dengan tuntas dan jelas. Pembuat undang-undang tidaklah mampu merangkum seluruh kehidupan manusia sehingga pada umumnya yang ditetapkan hanyalah peraturan yang bersifat umum saja, karena undang-undang tersebut hanya mencakup yang bersifat umum saja dan kadangkala tidak jelas dan lengkap maka hakim harus mencari dan menemukan hukumnya (rechtsvinding).

Berangkat dari konsep hukum progresif, penemuan hukum yang progresif, bahwa hukum itu adalah untuk manusia, yang didalamnya termasuk nilai-nilai akan kebenaran dan keadilan yang menjadi titik pembahasan hukum, sehingga faktor etika dan moralitas tidak terlepas dari proses terjadinya penemuan hukum

Menurut tafsir hermeneutika, rumusan suatu aturan hukum tertulis hanyalah simbol yang mengandung makna. Rangkaian kalimat dalam suatu peraturan hanyalah sekedar baju atau cangkang dari makna yang terkandung di dalamnya. Bagi tafsir ini, yang penting dan terutama adalah mencari makna dari rumusan suatu ketentuan perundangan sebagaimana dimaksud pembentuknya dahulu, lalu dipahami secara holistik dalam sistem hukum yang diterapkan dalam suatu kenyataan. Hermeneutika hukum merupakan suatu bentuk penemuan hukum yang lebih holistik dan bersifat progresif yang bersandarkan pada nilai-nilai hukum, kebenaran dan keadilan serta juga nilai etika dan moralitas. Hermeneutika juga merupakan alternatif penemuan hukum yang mampu menciptakan nilai-nilai baru dalam kehidupan masyarakat, atau melakukan rekayasa dalam suatu masyarakat yang sesuai dengan perkembangan zaman dan teknologi serta perkembangan masyarakat
\end{abstract}

Kata kunci : Hermeneutika, Penemuan Hukum, Hukum Progresif.

\section{ABSTRACT}

So broad aspects of human life that all human life can not be defined in a rule of law thoroughly and clearly. The lawmakers are not able to summarize all of human life that are generally set only the rules of a general nature only, because the law only covers a general nature only and is sometimes unclear and incomplete, the judge must seek and find legal (rechtsvinding).

Departing from the legal concept of progressive, progressive discovery of the law, that the law is for humans, which includes the values of truth and justice that is the discussion of the law, so the factor of ethics and morality can not be separated from the process of legal discovery 
According to the interpretation of hermeneutics, the formulation of a rule of written law is just a symbol that implies. A series of sentences in a regulation is merely a dress or shell of the meaning contained therein. For this interpretation, first and foremost, is to find the meaning of a formula of legislative provisions referred constituent first, then be understood holistically within the legal system applied in reality. Hermeneutics of law is a form of legal discovery is more holistic and progressive nature which relied on legal values, truth and justice as well as the ethics and morality. Hermeneutics is also an alternative legal discovery are capable of creating new values in public life, or engineered in a society that is in accordance with the times and technology and the development of society

Keywords: Hermeneutics, Invention Law, Progressive Law.

\section{Pendahuluan}

Aspek kehidupan manusia begitu luas sehingga seluruh kehidupan manusia tak bisa didefinisikan dalam suatu aturan perundang-undangan dengan tuntas dan jelas. Pembuat undang-undang tidaklah mampu merangkum seluruh kehidupan manusia sehingga pada umumnya yang ditetapkan hanyalah peraturan yang bersifat umum saja, maka hakim harus mencari dan menemukan hukumnya (rechtsvinding). Dari sinilah kita dapat mengetahui bahwa hukum itu senantiasa harus diketemukan sehingga hukum itu dapat terwujud dalam kenyataan. Tentu tidak hanya sekedar menerapkan peraturan perundang-undangan saja, tetapi perlu juga diperhatikan aspek-aspek lainnya karena hukum itu ada untuk manusia bukan sebaliknya, ini yang dapat dikatakan sebagai hukum yang bersifat progresif, hukum yang senantiasa mengabdi kepada kebutuhankebutuhan manusia akan kehidupannya.

Pada dasarnya setiap orang melakukan penemuan hukum. Setiap orang selalu berhubungan dengan orang lain, yang mana setiap orang akan berusaha menemukan hukumnya untuk diri sendiri, yaitu kewajiban dan wewenang apakah yang dibebaskan oleh hukum padanya. Penemuan hukum yang paling utama dilakukan oleh aparat hukum, baik itu hakim, jaksa dan lain-lain. Sudikno Mertokusumo dan A. Pitlo (1993:9) berpendapat bahwa memahami penemuan hukum yang harus diingat oleh aparat hukum adalah bahwa penemuan hukum bukan semata-mata hanya penerapan peraturan-peraturan hukum terhadap peristiwa konkret, tetapi sekaligus juga penciptaan hukum dan pembentukan hukum.

Pada hakekatnya semua perkara membutuhkan metode penemuan hukum agar aturan hukum baik itu tertulis maupun tidak tertulis dapat diterapkan secara tepat terhadap peristiwa hukum, sehingga dapat terwujud suatu hukum yang diidamkan, yaitu hukum yang mengandung aspek keadilan, kepastian hukum serta kemanfaatan.

Berkenaan dengan penemuan hukum, Eddy O.S. Hiariej (2009: 56) mengutip J.A. Pontier (2008:1) mengemukakan bahwa ada dua unsur penting dalam penemuan hukum. 
pertama, hukum/sumber hukum dan kedua adalah fakta. Pada awalnya, unsur hukum/sumber hukum dalam penemuan hukum adalah undangundang. Hal ini berkaitan dengan suatu postulat yang dikenal dengan istilah "De wet is onschendbaar" (undangundang tidak dapat diganggu gugat) yang dalam hukum Belanda tertuang secara explisit dalam Pasal 120 Grondwet. Akan tetapi, dalam perkembangannya, tidak semua hukum ditemukan dalam undang-undang. Oleh karena itu unsur hukum/sumber hukum dalam penemuan hukum tidak hanya meliputi undang-undang semata, tetapi juga meliputi sumber hukum lainnya, yaitu doktrin, yurisprudensi, perjanjian dan kebiasaan.

Dalam menegakkan hukum ada tiga unsur yang selalu harus diperhatikan : kepastian hukum (Rechtssicherheit), kemanfaatan (Zweckmassigkeit) dan keadilan (Gerechtigkeit). Hukum harus dilaksanakan dan ditegakkan. Setiap orang mengharapkan dapat ditetapkannya hukum dalam hal terjadi peristiwa konkrit. Bagaimana hukumnya itulah yang harus berlaku "fiat justitia et pereat mundus" (meskipun dunia ini runtuh hukum harus ditegakkan). Itulah yang diinginkan oleh kepastian hukum. Masyarakat mengharapkan adanya kepastian hukum, karena dengan adanya kepastian hukum masyarakat akan lebih tertib. Sebaliknya masyarakat mengharapkan manfaat dalam pelaksanaan atau penegakan hukum. Masyarakat sangat berkepentingan bahwa dalam pelaksanaan atau penegakan hukum, keadilan diperhatikan.
Berdasarkan konteks kekinian, munculnya kritik dari masyarakat terhadap putusan hakim menunjukkan kurang puasnya masyarakat terhadap kinerja pengadilan. Hal ini dapat ditemukan dari data empiris hasil jajak pendapat Harian Kompas (Shinta Dewi Rismawati, 2009 : 28) menunjukkan bahwa $72,7 \%$ rakyat belum mendapatkan perlakuan adil, dimana sebanyak 45,3\% responden menilai bahwa putusan hakim didasarkan pertimbangan uang, sebanyak 30,5 \% responden menilai karena pertimbangan politik dan hanya 9,3 \% responden yang masih percaya putusan pengadilan di Indonesia didasarkan pada pertimbangan hukum.

Keprihatinan terhadap kondisi hukum di Indonesia yang menurut pengamat hukum dari dalam maupun luar negeri, sebagai salah satu sistem hukum yang terburuk di dunia, sehingga hukum di Indonesia memberikan kontribusi yang rendah dalam turut mencerahkan bangsa untuk keluar dari keterpurukan.

Hal ini memicu munculnya gagasan hukum progresif. Menurut pendapat Satjipto Raharjo (2006 : 2) bahwa hukum itu adalah suatu institusi yang bertujuan mengantarkan manusia kepada kehidupan yang adil, sejahtera. Hal lain yang patut disadari bahwa hukum merupakan suatu produk dalam kehidupan manusia yang bermasyarakat, jadi untuk memahami kehidupan manusia kita juga harus memahami hukumnya.

Tetapi memahami hukum juga tak bisa terlepas dari memahami kenyataan kehidupan manusia sehari- 
hari. Dengan pemahaman yang mendalam tentang bagaimana cara memahami hukum yang benar tentu akan mengarahkan kita dalam melakukan suatu penemuan hukum yang baik. Untuk itulah hermeneutika hukum berusaha mencari dasar kefilsafatan bagaimana manusia memahami hukumnya melalui interpretasi.

Bernard Arief Sidharta (1999 : 94) mengungkapkan bahwa mula pertama hermeneutika itu dikembangkan adalah sebagai metode atau seni untuk menafsirkan teks. Kemudian lewat karya Scleiermacher dan Wilhelm Dilthey (Hans Georg Gadamer, 1965 : 289) mengembangkan dan menggunakan hermeneutika sebagai metode untuk ilmu - ilmu manusia, khususnya ilmu sejarah. Akhirnya, lewat karya Hegel dan karya Heidegger, Gadamer mengembangkan hermeneutika sebagai landasan kefilsafatan ilmu - ilmu manusia dalam bukunya "Truth and Method" . Dalam buku tersebut, Gadamer menyisishkan paragraph khusus dengan judul "The Exemplary Significance of Legal Hermeneutics" yang intinya berbicara mengenai signifikansi hermeneutika hukum. Kemudian dalam karya Heidegger dan karya Gadamer (B. Arief Sidharta, 1999 : 95-96), hermeneutika sebagai metode dikembangkan menjadi filsafat hermeneutika yang berintikan konsep-konsep kunci berikut: pendidikan (bildung), tradisi (ueberliefrung), prasangka (Vorurteil), pemahaman (verstehen), lingkaran hermeneutika (hermeneutische zirkel), pengalaman (erfahrung), sejarah pengaruh (wirkungsgeschichte), kesadaran sejarah pengaruh (effective historical conciousness), dan perpaduan cakrawala (fusion of horizons).

\section{Rumusan Masalah}

Berdasarkan latar belakang masalah diatas, penulis dapat menarik suatu permasalahan yang akan dikaji dalam tulisan ini, yaitu :

1. Metode penemuan hukum yang progresif patut disadari sebagai upaya alternatif yang dapat ditempuh oleh para penegak hukum untuk mengantisipasi terjadinya kekosongan hukum dalam sebuah aturan hukum positif demi terwujudnya tujuan hukum. Dengan begitu, bagaimana metode penemuan hukum dalam perspektif hukum progresif?

2. Bagaimana Implementasi metode hermeneutika guna menciptakan penemuan hukum yang progresif?

\section{Pembahasan \\ Metode Penemuan Hukum yang Progresif}

Masalah penemuan hukum dalam kaitannya dengan tugas hakim adalah muncul pada saat hakim melakukan pemeriksaan perkara hingga saat menjatuhkan putusan. Hakim dalam menjalankan tugas dan wewenangnya memeriksa, mengadili dan kemudian menjatuhkan putusan harus didasarkan pada hukum yang berlaku dan juga berdasarkan keyakinannya, bukan berdasarkan logika hukum semata. Menurut Bagir Manan (2005 : 209), rumusan undang-undang yang bersifat umum tidak pernah menampung secara pasti setiap peristiwa hukum. Hakimlah yang berperan menghubungkan atau menyambungkan peristiwa hukum 
yang konkret dengan ketentuan hukum yang abstrak.

Menurut Achmad Ali sebagaimana dikutip oleh Yudha Bhakti Ardhiwisastra (2000 : 19) ada 2 (dua) teori metode penemuan hukum yang dapat dilakukan oleh hakim dalam praktik peradilan, yaitu antara lain :

a. Metode Interpretasi Hukum Interpretasi merupakan penjelasan setiap istilah dari suatu perjanjian apabila terdapat pengertian ganda atau tidak jelas dan para pihak memberikan pengertian yang berbeda terhadap istilah yang sama atau tidak dapat memberikan arti apa pun terhadap istilah tersebut. Tujuan utama interpretasi adalah menjelaskan maksud sebenarnya dari para pihak atau merupakan suatu kewajiban memberikan penjelasan mengenai maksud para pihak seperti dinyatakan dalam kata-kata yang digunakan oleh para pihak dilihat dari keadaankeadaan yang mengelilinginya.

b. Metode Konstruksi Hukum

Salah satu metode yang akan digunakan oleh hakim pada saat ia dihadapkan pada situasi adanya kekosongan hukum (rechts vacuum) atau kekosongan undang-undang (wet vacuum), karena pada prinsipnya hakim tidak boleh menolak perkara untuk diselesaikan dengan dalih hukumnya tidak ada atau belum mengaturnya (asas ius curia novit). Hakim harus terus menggali dan menemukan hukum yang hidup dan berkembang ditengah-tengah masyarakat, karena sebagai penegak hukum dan keadilan, hakim wajib menggali, mengikuti dan memahami nilai-nilai hukum dan rasa keadilan yang hidup dalam masyarakat.
Ahmad Rifai (2010 : 4) membagi karakteristik penemuan hukum yang progresif adalah :

a. Penemuan hukum yang didasarkan atas apresiasi hakim sendiri dengan dibimbing oleh pandangannya atau pemikirannya secara mandiri, dengan berpijak pada pandangan bahwa hukum itu ada untuk mengabdi kepada manusia.

b. Penemuan hukum yang bersandarkan pada nilai-nilai hukum, kebenaran dan keadilan, serta juga etika dan moralitas.

c. Penemuan hukum yang mampu menciptakan nilai-nilai baru dalam kehidupan masyarakat, atau melakukan rekayasa dalam suatu masyarakat yang sesuai dengan perkembangan zaman dan teknologi serta keadaan masyarakat.

Secara faktual, tidak dapat ditentukan metode penemuan hukum yang bagaimanakah yang dapat digunakan hakim dalam melakukan penemuan hukum yang sesuai dengan karakteristik penemuan hukum yang progresif, karena dalam setiap perkara atau kasus mempunyai bentuk dan karakteristik yang berlainan atau variatif sifatnya. Sehingga hakim akan menggunakan metode penemuan hukum yang sesuai dengan kasus yang dihadapinya (case by case), apakah itu salah satu metode interpretasi hukum ataukah salah satu dari metode konstruksi hukum atau hanya berupa gabungan dari beberapa metode interpretasi hukum atau konstruksi hukum, ataukah sekaligus dari metode interpretasi hukum dan konstruksi hukum sekaligus. Putusan hakim yang demikian diharapkan dapat mendorong pada perbaikan dalam 
masyarakat dan membangun harmonisasi sosial dalam pergaulan antar anggota masyarakat serta dapat dipergunakan sebagai sumber pembaharuan hukum.

\section{Hermeneutika Hukum sebagai Penemuan Hukum yang Progresif.}

Friedrich Schleiermacher

(Richard E. Palmer, 2005 : 95) mendefinisikan hermeneutik sebagai seni memahami, sementara Paul Ricoeur (1990 : 43) mendefinisikan, hermeneutik adalah teori operasi pemahaman dalam hubungannya dengan interpretasi teks (hermeneutics is the theory of the operations of understanding in their relation to the interpretation of texts). Penafsiran untuk mencari makna suatu aturan sebagaimana dimaksud oleh pembentuknya dahulu disebut penafsiran hermeneutika. Secara etimologi, hermeneutika berasal dari kata Hermes, nama salah seorang Dewa Yunani yang berarti 'Pembawa Berita'. Menurut Gadamer, sebagai mana dikutip oleh Ahmad Rifai (2010 : 87) "Legal hermeneutics is then, in reality no special case but is, in contrary fitted to restore the full scope of the hermeneutical problem and so to retrieve the former unity of hermeneutics, in which jurist and theologian meet the student of humanities." (yang secara bebas dapat diartikan sebagai: "Hermeneutika hukum dalam kenyataannya bukanlah suatu hal yang khusus, tetapi sebaliknya ia hanya merekonstruksikan seluruh problem hermeneutika dan kemudian membentuk kembali kesatuan hermeneutika itu secara utuh, dimana para ahli hukum dan para teologis bertemu dengan mereka-mereka yang mendalami peri kemanusiaan.").

Gustav Radbruch termasuk orang yang sangat tidak setuju dengan metode penafsiran hermeneutika. Dalam bukunya "Outline of Legal Philosophy". Radbruch mengatakan bahwa suatu ketentuan undangundang harus dicari maknanya sendiri melampaui apa yang dimaksud oleh pembentuknya dahulu dengan menggunakan penafsiran trans empiris (trans-empirical interpretation).

Menurutnya, suatu peraturan harus dimaknai sesuai dengan konteks pemahaman ketika hukum itu akan diterapkan, tidak harus terikat dengan maksud pembentuknya dahulu. Memaknai suatu peraturan perundangan dengan mengacu kepada maksud pembentuk undang-undang dahulu akan menghasilkan kumpulan pandangan dari para pembentuknya yang mungkin memiliki gap (jurang) antara pandangan yang satu dan pandangan lainnya, yang juga belum tentu masih relevan dan sesuai dengan konteks atau situasi yang dihadapi pada saat hukum itu akan diterapkan, sementara hukum memerlukan kepastian makna untuk memberikan suatu kepastian hukum pada suatu kenyataan.

Lebih lanjut Radbruch mengemukakan bahwa sama halnya dengan suatu teka-teki dapat menimbulkan suatu jawaban yang benar sesuai konteks waktu, yang mungkin sama atau sama sekali berbeda dengan jawaban yang dimaksud oleh si pembuat teka-teki tersebut pada saat membuat teka-teki itu, demikian juga halnya undang- 
undang, itu dapat mempunyai makna yang meskipun terlepas dan sama sekali berbeda dengan yang dimaksud oleh pembentuk hukum itu dahulu, akan tetapi dapat diterapkan pada dan sesuai dengan suatu konteks tertentu pada saat tertentu.

Penulis dalam hal ini tidak sependapat dengan Gustav Radbruch. Dengan melepaskan makna suatu ketentuan undang-undang dari apa yang dimaksud oleh dan menjadi tujuan pembentuknya dahulu, maka suatu undang-undang itu akan kehilangan roh atau cita-cita (rechtsidee) dari para pembentuknya dahulu untuk mana mereka membuat ketentuan-ketentuan itu.

Keadaan demikian itu juga akan semakin menjauhkan hukum dari tugasnya semula, ialah untuk mengarahkan para justiabelen atau subjek hukum itu mencapai tujuan yang dimaksud oleh pembuat hukum itu dahulu (law as a tool of social enginering), yaitu tujuan dari negara sebagai pembentuk hukum. Akibat yang lebih jauh lagi dari keadaan itu ialah bahwa hukum tidak lagi mengatur otoritas pelaksana hukum guna mencapai tujuannya, melainkan pelaksana hukumlah yang akan mengatur dan melaksanakan hukum sesuai dengan kepentingan dan/ atau kenyataan yang dihadapinya dari masa ke masa.

Jazim Hamidi $(2005:$ 2)
berpendapat bahwa esensi
hermeneutika adalah pemahaman
melalui interpretasi. Berdasarkan
pandangan bahwa kegiatan dalam
kehidupan manusia sangat luas, tidak
terhitung jumlah dan jenisnya,
sehingga tidak mungkin tercakup

dalam suatu peraturan perundangundangan dengan tuntas dan jelas, maka dari itu hukum itu harus diketemukan agar terdapat kesesuain dengan kenyataan dan disanalah terjadi proses hermeneutika. Gadamer (Gregory Leyh, 2008 : 1-2) menambahkan bahwa hermeneutika dalam kenyataannya bukanlah merupakan suatu kasus khusus/baru, tetapi sebaliknya, ia hanya merekonstruksi kembali dari seluruh problematika hermeneutika dan kemudian membentuk kembali kesatuan hermeneutika secara utuh, dimana ahli hukum dan teologi bertemu dengan ahli humaniora/ilmu kemanusiaan.

Dalam kenyataan memang pembuat undang-undang hanya menetapkan peraturan yang bersifat umum saja, dan pertimbangan tentang hal-hal konkret diserahkan kepada hakim jadi hakimlah yang mempunyai kebebasan untuk menentukan hukum itu dalam kenyataan di depan persidangan dan dapat memberikan sentuhan human pada hukum dan peraturan perundang-undangan. Dari sana hakim melakukan penemuan hukum, Sudikno Mertokusumo (1993 : 4) juga mengatakan karena undangundang tidak lengkap hakim harus melakukan penemuan hukum penegakkan dan pelaksanaan hukum sering merupakan penemuan hukum dan tidak sekedar penerapan hukum.

Hermeneutik digunakan tidak hanya berkaitan dengan masalah pengertian dengan arti ganda, tetapi berhubungan dengan seluruh kenyataan bahasa dan dengan suatu teks. Fungsi simbolik dan interpretasi harus diinterpretasikan dalam konteks 
yang lebih pasti dari teks, sehingga didalam mengguanakan interpretasi harus diketahui proses dari interpretasi yang berkepentingan untuk menghindari distorsi pemahaman dan bertujuan mencari kebenaran (correctenes).

Teks dalam pengertiannya adalah setiap diskursus yang dibakukan dalam tulisan. Suatu teks menempatkan diskursus lewat tulisan. Sebagai diskursus dialektis peristiwa-arti dan dialektika arti referensi berlaku pula pada teks (W. Poespoprodjo, 2004 : 122). Menurut definisi ini, pembakuan lewat tulisan merupakan ciri konstitutif dari teks itu sendiri sehingan dengan demikian apa yang dibakukan oleh tulisan adalah diskursus yang memang dapat diucapkan, dan pembekuan melalui tulisan menempati posisi ucapan. Sebuah teks baru akan menjadi teks ketika langsung membubuhkan apa yang dimaksudkan oleh diskursus ke dalam huruf-huruf tertulis.

Hubungan langsung antara makna dan pernyataan dan tulisan dapat didukung dengan melihat pada pembaca dan hubungan dengan tulisan. Tulisan yang menjadi teks memerlukan pembaca melalui cara yang memungkinkan pembaca untuk langsung memperkenalkan konsepkonsep interpretasi. Teks adalah tempat munculnya seorang pengarang sehingga muncul relasi antara keduanya yang bisa dikatakan bahwa pengarang teks dilembagakan oleh teks.

Penjelasan dan interpretasi akan saling berhadapan dalam tindakan membaca. W. Dilthey (1976 : 248) mengemukakan pendapat mengenai dualitas antara penjelasan dan interpretasi. Menurut Dilthey pembaca dari suatu teks sebetulnya bukanlah antara penjelasan dan interpretasi melainkan antara penjelasan dan pemahaman karena interpretasi adalah wilayah khusus yang dijadikan dari bagian pemahaman. Selanjutnya Dilthey mengatakan bahwa pemahaman merupakan proses yang membuat individu tahu sesuatu menganai kehidupan mental melalui tanda-tanda yang harus dipahami yang merepresentasikan kehidupan mental itu.

Disinilah dibutuhkan Hermeneutika sebagai metode yang dapat menerangkan makna dari dokumen hukum yang berkaitan dengan konteks sekarang. Hermeneutik berhubungan dengan konsep memahami dan interpretasi.

\section{Simpulan}

a. Dengan mendasarkan pada karakteristik penemuan hukum yang progresif tersebut diatas, maka dapat dijelaskan metode penemuan hukum yang progresif adalah sebagai berikut:

1) Metode penemuan hukum yang bersifat visioner dengan melihat permasalahan hukum tersebut untuk kepentingan jangka panjang ke depan dengan melihat case by case.

2) Metode penemuan hukum yang berani dalam melakukan suatu terobosan (rule breaking) dengan melihat dinamika masyarakat, tetapi berpedoman pada hukum, kebenaran, dan keadilan serta memihak dan peka pada nasib dan keadaan bangsa dan negaranya. 
3) Metode penemuan hukum yang dapat membawa kesejahteraan dan kemakmuran masyarakat dan juga dapat membawa bangsa dan negara keluar dari keterpurukan dan ketidakstabilan sosial seperti saat ini.

b. Metode Hermeneutika dapat dikatakan sebagai metode penemuan hukum yang progresif, dengan berbagai alasan sebagai berikut:

1) dapat dikatakan sebagai suatu metode penemuan hukum. pada dasarnya hermeneutika hukum tidak terpisah dengan metode penemuan hukum lainnya, Hermeneutika hukum hanya merangkum seluruh metode penemuan hukum yang ada dalam kesatuan pemahaman yang lebih holistis dengan bingkai keterkaitan antara teks, konteks, dan kontekstualisasinya.

2)

Hermeneutika hukum sesuai dengan karakteristik penemuan hukum yang progresif. Hermeneutika hukum dalam melaksakan perannya selalu berhati-hati karena senantiasa meperhatikan keterkaitan anatara teks, konteks, dan kontekstualisasinya. Dan dalam praktik yang terjadi pada kasus Marbury vs Madison hermeneutika hukum terbukti mampu menciptakan hukum yang lebih progresif

\section{Saran}

Sebagaimana yang disebut tentang metode penemuan hukum dalam perspektif hukum progresif, maka saran-saran yang dapat penulis sampaikan adalah agar putusan hakim sesuai dengan metode penemuan hukum yang progresif yaitu antara lain:

a. Putusan hakim tidak hanya semata-mata bersifat legalistik, yakni hanya sekedar corong undang-undang (la bouche de la loi) meskipun seharusnya hakim selalu harus legalistik karena putusannya tetap berpedoman pada peraturan perundangundangan yang berlaku.

b. Putusan hakim tidak hanya sekedar memenuhi formalitas hukum atau sekadar memelihara ketertiban saja, tetapi putusan hakim harus berfungsi mendorong perbaikan dalam masyarakat dan membangun harmonisasi sosial dalam pergaulan

c. Putusan hakim yang mempunyai visi pemikiran kedepan (visioner), yang mempunyai keberanian moral untuk melakukan terobosan hukum (rule breaking), dimana dalam hal suatu ketentuan undangundang yang ada bertentangan dengan kepentingan umum, kepatutan, peradaban, dan kemanusiaan yakni nilai-nilai yang hidup dalam masyarakat, maka hakim bebas dan berwenang melakukan tindakan contra legem, yaitu mengambil putusan yang bertentangan dengan pasal undang-undang yang bersangkutan dengan tujuan untuk mencapai kebenaran dan keadilan.

d. Putusan hakim yang memihak dan peka pada nasib dan keadaan bangsa dan negaranya yang bertujuan pada peningkatan kesejahteraan untuk kemakmuran 
ISSN : 2356-4164

masyarakat serta membawa bangsa dan negaranya keluar dari keterpurukan dalam segala bidang kehidupan.

\section{Daftar Pustaka}

Ardhiwisastra, Yudha Bhakti, 2000. Penafsiran dan Konstruksi Hukum, Alumni, Bandung.

Dilthey, W., 1976. The Development of Hermeneutics in Selected Writings, (terj) H. P. Rickman, Cambridge University Press, Cambridge.

Gadamer, Hans Georg, 1965. Truth and Method terjemahan oleh Ahmad Sahidah, Kebenaran dan Metode, Pengantar Filsafat Hermeneutika, Pustaka Pelajar, Yogyakarta.

Hamidi, Jazim, 2005. Hermeneutika Hukum, Teori Penemuan Hukum Baru dengan Interpretasi Teks, UII Press, Yogyakarta.

Hiariej, Eddy O.S., 2009. Asas Legalitas dan Penemuan Hukumdalam Hukum Pidana, Erlangga, Jakarta.

Manan, Bagir, 2005. Suatu Tinjauan terhadap Kekuasaan Kehakiman dalam Undang-Undang Nomor 4 Tahun 2004, Mahkamah Agung RI, Jakarta.

Mertokusumo, Sudikno, dan A. Pitlo, 1993. Bab-bab Tentang Penemuan, Citra Aditya Bakti, Bandung.

Palmer, Richard E., 2005. Hermeneutika Teori Baru Mengenal Interpretasi (terj.) Hermeneutics Interpretation Theory in Schleiermacher, Dilthey, Heidegger and Gadamer, cetakan
Kedua, Pustaka Pelajar, Yogyakarta.

Poespoprodjo, W., 2004. Hermeneutika, Pustaka Setia, Bandung.

Pontier, J.A., 2008. Penemuan Hukum, Penerjemah B. Arief Sidharta, Jendela Mas Pustaka, Bandung.

Rahardjo, Satjipto, 2006. Hukum Progresif sebagai Dasar Pembangunan Ilmu Hukum Indonesia, sebagaimana terdapat dalam Menggagas Hukum Progresif Indonesia, Pustaka Pelajar.

Ricoeur, Paul, 1990. Hermeneutics and Human Sciences, John B. Thompson (terj. Dan ed.) Cambridge University Press.

Rifai, Ahmad, 2010. Penemuan Hukum oleh Hakim Dalam Perspektif Hukum Progresif, Sinar Grafika, Jakarta.

Rismawati, Shinta Dewi, 2009. Hermeneutika Hukum: Upaya Menangkap Makna Keadilan Dalam Teks (Sebuah Tawaran Alternatif dan Solutif), Jurnal Ilmiah Hukum dan Dinamika Masyarakat, Vol.7 No. 1 Oktober 2009, Semarang: Fakultas Hukum Universitas Tujuh Belas Agustus.

Sidharta, B. Arief, 1999. Refleksi Tentang Struktur Ilmu Hukum, Mandar Maju, Bandung. 